\title{
Sterilization and Inflation in the Long-Term Empirical Evidence from Egypt
}

\author{
Emad Omar Elhendawy ${ }^{1}$ \\ ${ }^{1}$ College of Business Administration, Higher Technological Institute Tenth of Ramadan city, Egypt \\ Correspondence: College of Business Administration, Higher Technological Institute, Tenth of Ramadan city, Cairo, \\ Egypt.
}

Received: March 4, 2015

doi:10.11114/aef.v2i2.757
Accepted: March 18, 2015

Available online: April 7, 2015

\begin{abstract}
Although many central banks actively sterilized intervention, there is still no consensus on sterilized effect on the inflation in the long - term. This study aims at answering the question of whether or not sterilized intervention by the central bank of Egypt causes inflation in the long term. In this paper we use annual data from 1980 to 2011 and use Granger Causality test, Error Correction model (VECM) and Variance Decomposition. The causal relationship between sterilization and inflation rustles indicate that, there is a bi-directional causality in two and three lags and inflation cause sterilization in four and five lags, that any intervention by the central bank sterilization in Egypt is causing inflation in the period 1980-2011. The VECM results clearly indicate the existence of a long run positive relationship between sterilization and inflation, where sterilization value increased by $10 \%$ the change in inflation will be $22 \%$ in long - term, but in the short term, all the independent variables were not significant except for the impact of inflation on the same, it is positive and significant. This means that the results of the intervention of the Central Bank of Egypt through the sterilization policy does not limit the inflation in the short term but lead to increased rates of inflation in the long term through the influence in the fiscal deficit, as the sterilization value increased by $10 \%$ the change in budget deficit will be $4.4 \%$. The variance decomposition rustles indicates that the relative importance (contrast ratio prediction error interpreter) for a shock occur in sterilization in the interpretation of the change in inflation is positive, continuing and growing, this importance was $1.56 \%$ in the second year of shock and then $5.49 \%$ in the third year of the shock and then $10.94 \%$ in the fourth year and so that up to $45.42 \%$ in the tenth year of the shock. This indicates that there is a positive, growing and continuing relationship between sterilization and inflation in Egypt in the period of study.
\end{abstract}

Keywords: sterilization, inflation, Granger Causality, Error Correction model, variance decomposition, Egypt.

\section{Introduction}

When central banks Change their net foreign assets, this tends to cause changes in the domestic monetary base. But for purposes of monetary policy, Central banks may want to insulate the domestic monetary base from such changes. The policy followed by central banks to make such insulation is known as sterilization. In fact sterilization policy is usually pursued in order to subdue inflationary pressures emanating from reserve accumulation. For instance in the event that a central bank wants to prevent an appreciation in domestic currency it will purchase foreign currency. To keep such purchases from affecting the size of net foreign assets, the central bank issues bonds in the domestic market. This procedure siphons away the added money supply resulting from the foreign exchange purchases such that it does not impinge on domestic interest rates or inflation. It would be quite useful to pose the concept of sterilization in terms of a couple of known identities. The first identity postulates that the change in net foreign assets holdings of a central bank is nothing but the sum of the current account (CA) and the capital account (CAP). This is the so called balance of 
payments identity which may be represented by the following equation:

$$
\triangle \mathrm{NFA}=\mathrm{CA}+\mathrm{CAP}
$$

Assume that at a certain level of the exchange rate, the current account (CA) in an economy is in a state of balance $(\mathrm{CA}=0)$, but that the expected returns on its assets exceed their counterparts in other countries. This would trigger inflows of capital from other countries resulting in the accumulation of foreign currency (e.g. US dollars) and a tendency for domestic currency to appreciate. However, if this country wants to maintain its local currency value, the country's central bank will enter the foreign exchange market and purchase US dollars thus raising its foreign assets reserves. The upshot of this operation is therefore an inward capital flow which means a rise in foreign assets (CAP $>0$, $\triangle \mathrm{NFA}>0$ ). Alternatively, if the central bank keeps a hands- off policy, there will be an appreciation in the exchange rate which is large enough to quell further capital inflows since it won't pay for capital to keep following, At that point, a balance of payments equilibrium would have been reached with $\mathrm{CAP}=0$ and $\triangle \mathrm{NFA}=0$. The foregoing analysis probably illustrates that the balance of payments conditions (current account and capital account) in a country and its foreign exchange rate policies are the prime drivers of changes in the central bank foreign assets holdings (Moreno, 1996). In addition, the stripped down version of the central bank balance sheet presented in table 1 below drives home the point that central bank assets indeed change commensurately with changes in money reserves or the monetary liabilities of the central bank. A change in central bank assets would also equal changes in central bank net domestic assets (NDA) plus changes in its net foreign assets (NFA).

Table 1. A stylized Central Bank (C.B) Balance Sheet

\begin{tabular}{cc}
\hline Assets & Liabilities \\
\hline$\cdot$ Net domestic assets (NDA) & $\bullet$ Reserve money ( R ) \\
(Government bonds) & currency (CC) \\
$\bullet \begin{array}{c}\text { Net foreign assets (NFA) } \\
\text { (Reserves ) }\end{array}$ & reserve deposits (RD) \\
\hline
\end{tabular}

The manner in which the central bank balance sheet is presented in table 1 is particularly useful in exposing owsterilization works since it states the balance sheet in terms of net amounts. Thus the assets side of the central bank balance sheet comprises such items as net domestic assets (largely government bonds) and net foreign assets (mainly official reserves). As for the liabilities, these include the bank reserve money which is made up of circulating currency (CC) and reserve deposits of commercial banks. Changes in reserve money must invariably cause NDA or NFA to change too. Further, a change in NFA also changes money supply as can be seen in equation (2) below.

$$
\Delta \mathrm{R} \equiv \Delta \mathrm{NDA}+\Delta \mathrm{NFA}
$$

Central banks may sometimes wish to insulate reserve money from the effects of changes in net foreign assets. This can be done by making counter- changes in NDA. The latter procedure is known as the sterilization policy (Moreno, 1996). It is a policy whereby the Central bank seeks to neutralize a change in NFA by adjusting its NDA or appropriately changing reserve deposits. There are several ways to carry out this policy but an open market operation (OMO) is probably the most widely used technique. This technique involves selling bonds by the central bank in the "open market" so as to cut back the excess in money supply resulting from the acquisition of assets denominated in US dollars. The quotient of the change in NDA to the change in NFA $(\triangle \mathrm{NDA} / \Delta \mathrm{NFA})$ is referred to in the literature as the OMO ratio (Lavigne, 2004). It is an indication of how much reserve accumulation was neutralized by OMO.

As stated above, other techniques do exist for reducing the liquidity glut created by the manipulation of central bank NFA (Lavigne, 2008). One such technique is that of depositing government budget surpluses for instance in central bank accounts. Such an action in fact boils down to the same thing as selling bonds in the open market since it siphons off money from the financial system. Such policies may be termed market- oriented.

Under some sterilization techniques, commercial banks may have to acquire bonds rather than purchase them willingly. Such techniques would have banks hold a larger volume of instruments of sterilization or possibly at a lower price than they would otherwise opt for if the market were free. Thus under such techniques commercial banks may have to endure forcible purchases of bonds at lower interest rates, involuntary lending to the central bank or face a rice in their required reserve ratio. In emerging countries, the latter technique is particularly important. (Lavigne. 2004) It features the central bank raising the reserve requirements of commercial banks in a way that keeps the increased monetary base following reserve accumulation from impinging on the currency in circulation, which greatly influences the money supply. If the overall effects of sterilization policies are to be measured, such a measure should include both the market- oriented and non- market- oriented policies alluded to above. In effect total sterilization may be measured using the ratios $(\triangle \mathrm{RD}$ $\Delta \mathrm{NDA}) / \triangle \mathrm{NFA}$ or $(\triangle \mathrm{NFA}-\Delta \mathrm{CC}) / \Delta \mathrm{NFA}$.

The values of the ratios fall between 0 (no sterilization) and 1 (complete sterilization) at such times when the 
appreciation of currencies stimulates reserve accumulation. By and large, sterilization is considered ineffective in developed countries (Mundell, 1968), but appears to be more effective in developing countries (Disyatat and Galati, 2005). The reason for this is probably that financial securities are not generally good substitutes for international assets denominated in dollars. Indeed if foreign assets and the local securities were perfectly substitutable, intervention policy would lose its potency. Thus an intervention policy aimed at prohibiting a rise in the exchange rate would at the outset raise domestic interest rates and as result create a gap between local and international interest rates. If domestic assets were completely substitutable with foreign assets this interest gap would quickly disappear as a result of inflows of short- term foreign capital. (As was the case in Colombia in 1991 and Malaysia 1991-1992) which would culminate in a currency appreciation and a reversal of the initial fall of local currency value (Reinhart \& Khan, 1995). However in the absence of substitutability, the interest gap may not be eliminated which means that the effect of the intervention on the exchange rate will not be eliminated altogether. There are several factors that may be held responsible for the less than perfect substantiality between local and foreign assets in developing countries such as the quality of institutions, political stability and the economic structure of the country. Nonetheless, it appears the prime factor in this respect is the presence of wide ranging capital controls in less developed countries With these controls, asset inflows and outflows are hampered which implies that the sterilization procedure will eventually affect the exchange rate since the effect of the inflow of foreign assets will not be completely neutralized. The rest of this chapter is organized as follows: Section 2 gives the literature review.

Section 3 outlines monetary policy and the mechanism of monetary transmission in Egypt. Section 4 presents the methodology and model estimation. Finally section 5 gives the results and conclusion.

\section{Literature Review}

Using a dynamic perfect foresight simulation model, Obstfeld set out to test for the specific question of whether the Bunds bank could attain independent internal and external goals over a short run period of one month given imperfect substitutability between foreign and domestic bonds. His findings indicated that sterilized intervention has significant albeit short- lived exchange rate effects that wither away in thirty days (Obstfeld, 1982). Despite the fact that the sustainability of sterilized intervention remains a debatable issue, some measure of consensus has been reached on some related issues; first, the effectiveness of sterilization is only a short run phenomenon but it can't influence the exchange rate permanently (Edison, 1993).

Second, so far as interest rate on domestic bonds exceeds its counterpart on foreign exchange reserves, quasi- fiscal costs will be incurred. In some Latin American countries, these costs were estimated to be in the order of 0.25 to 0.50 of GDP (Reinhart and Khan, 1995). Cun and Li examined the effectiveness of sterilization in terms of controlling domestic inflation and they build a two country DSGE model with a banking sector which produces liquidity that is used in transaction by combing collateral and monitoring labour. In addition, they incorporate into the features of emerging economic markets including capital account controls, foreign exchange market intervention, and sterilization. They calibrated their model to Chinese data and simulated the model .They found that sterilization can help control inflation but have only limited effectiveness. Moreover ,they found full sterilization greatly increases the holdings of government bonds by the private sector, which leads to quasi fiscal cost of government, especially when domestic interest rates are lower than foreign interest rates and the benefit of sterilization could be small compared with its cost (Cun and Li, 2013). Indeed in the event that a central bank holds foreign assets denominated in major world currencies and which earn lower interests than the domestic securities held at the bank, operating losses will be incurred. Unduly large losses may even necessitate that the central bank be recapitalized. Indeed the structural malformation of a central bank or treasury balance sheet may considerably raise the credit risks for the bank and possibly instigate an unexpected reversal in the direction of capital flows. This possibility will be greater when the bulk of capital inflows are made up of shortterm portfolio investment which can turn back and exit the country much more quickly than foreign direct investment (Yung Lee, 1997). Furthermore, such losses may hurt the central bank and undermine its independence and credibility (Dalton and Dziobek, 2005).

Third, the increased public debt resulting from sterilization may generate higher inflation expectations in the economy. In the final analysis sterilized intervention does not have an internal mechanism which can prevent inflation (calvo, 1991). In fact our study aims at answering the question of whether or not sterilized intervention by the central bank of Egypt causes inflation in the long run.

\section{Monetary Policy and Monetary Transmission Mechanism Channels in Egypt}

In steering its monetary policy, the central bank of Egypt had consistently sought to achieve the twin objectives of price and exchange rate stability during the period 1990/1991 and up to 1998/1999. In the process, the central bank of Egypt used various quantitative and price instruments at different points in time to reach those objectives. The central bank used its own excess reserves in local currency along with short term nominal interest rate as operating targets. Control of growth in the monetary aggregate (M2) was the intermediate target. The policy instruments used by the 
central bank consisted of such indirect market tools as open market operations, required reserve ratio and interest rates (e.g. the discount rate, 3 month deposit rate, less- than - one year loans and Treasury bills rate). For example the period in question witnessed the most extensive sterilization process using the open market operations tool since the debut of the Economic Reform and Structural Adjustment Program by the Government of the Arab Republic of Egypt. Such an action was necessary in order to maintain the value of the nominal exchange rate at a time when foreign capital was flowing in at full swing reaching as high as us $\$ 400$ million in 1994. However, the fiscal burden of sterilization rose considerably as a result (CBE Economic Review 2009/2010).

The central bank switched policies in the period 2000-2004 and started a conjoint effort with the government to sell securities in a sterilized intervention. Meanwhile an overnight interbank market for domestic currency was introduced in 2001 to help track the variations of macroeconomic variables. This however did not work well due to the volatility of this indicator. The economy appeared to have lost its sense of direction because of the conflicting nature of fiscal and monetary policies. A number of quantitative and price instruments were used by the cen tral bank in its endeavor to achieve an array of desired objectives, but the result was detraction and inconsistency in monetary policy management (CBE Economic Review 2009/2010).

The years spanning the period 2005-2010 witnessed a glut in the money supply and a sterilized intervention following the rise in foreign assets. Consequently the interbank rate (operational target) slipped moving closer to the lower end of the spectrum, leaving the CBE no choice but to step in using open market operations to elimi nate the excess. The CBE would go about carrying out such operations either by using its longtime instruments such as Treasury Bills, acceptances of interest bearing deposits, newly crafted securities such as CB notes with maturity dates not exceeding two years or short run (one year or less) CBE deposit certificates sold directly to the commercial banks. The last two instruments were first put into use during the fiscal year 2005/2006. Additionally, the CBE also resorted anew to its longstanding tradition of deposit auctions in 2007 which have since become the foremost apparatus in combating inflation originating from higher money supply. (CBE Economic Review 2009/2010).

\section{Methodology and Model Estimation}

To be able to address the question of whether or not sterilization is indeed a major cause of inflation in Egypt, it might be appropriate to start by testing for the stationary of all the variables in our model, namely inflation, sterilization, budget balance and domestic credit provided by the banking sector. In the event that the variables show non stationary, the next step would naturally be to test for the existence of a long run co integration relationship linking inflation to the other "explanatory" variables. The existence of such a relationship would presumably warrant the use of an error correction model to carry out the tests in question. However, barring the existence of a long run co integration relationship, it would not be necessary to apply the co integration apparatus because in their well- publicized work, Engel and Granger (1987) pose the ECM model as a means of representing co integration variables. While this method of representation has the advantage of incorporating the dynamics of equilibrium in the short run, it also portrays whether and how the variables deviate temporarily from their predicted long run equilibrium values. At any rate, and with co integration relationship between inflation and sterilization firmly in place, an ECM equation of the following form might be estimated:

$$
\text { INFLATION }=\alpha+\delta \text { STER }+\gamma \text { BUDGET }+\psi \text { DCREDIT }+\mathrm{u}_{\mathrm{i}}{ }^{1}
$$

The variables are defined as follows:

INFLATION: consumer prices percent change (annual \%) ${ }^{2}$

STER: sterilization $(\Delta \mathrm{NDA} / \Delta \mathrm{NFA})^{3}$

BUDGET: (budget Deficit or surplus / GDP) \%

DCREDIT: Domestic credit provided by banking sector (\% of GDP) ${ }^{4}$

\footnotetext{
1 - $\mathrm{U}_{\mathrm{i}}$ : White-noise error term.

2 - World Economic Outlook (WEO) data, IMF http://www.econstats.com/weo/CEGY.htm

3 - CBE Financial Position Reserve Money and Counterpart Assets :

http://www.cbe.org.eg/Excel/CBE/1-CBE_Financial_Position_Reserve_Money_and_CCounterpart_Assets.xls.

4 - Domestic credit provided by the financial sector includes all credit to various sectors on a gross basis, with the exception of credit to the central government, which is net. The financial sector includes monetary authorities and deposit money banks, as well as other financial corporations where data are available (including corporations that do not accept transferable deposits but do incur such
} 
The study uses annual time series data covering the period 1980-2011, except for the sterilization series which start only in 1991. The data were obtained mainly from the International Financial Statistics, the World Bank Indicators (WDI) and the Central Bank of Egypt. The Hedrick and Prescott filter (HP) was used to compute the long run or permanent values of the variables. This (HP) filter is a device whereby the cycle effects on a time series are set apart from the raw data such that only long run changes in a time series are essentially reflected in a variable's movements (Hedrick and Prescott, 1997) ${ }^{5}$.

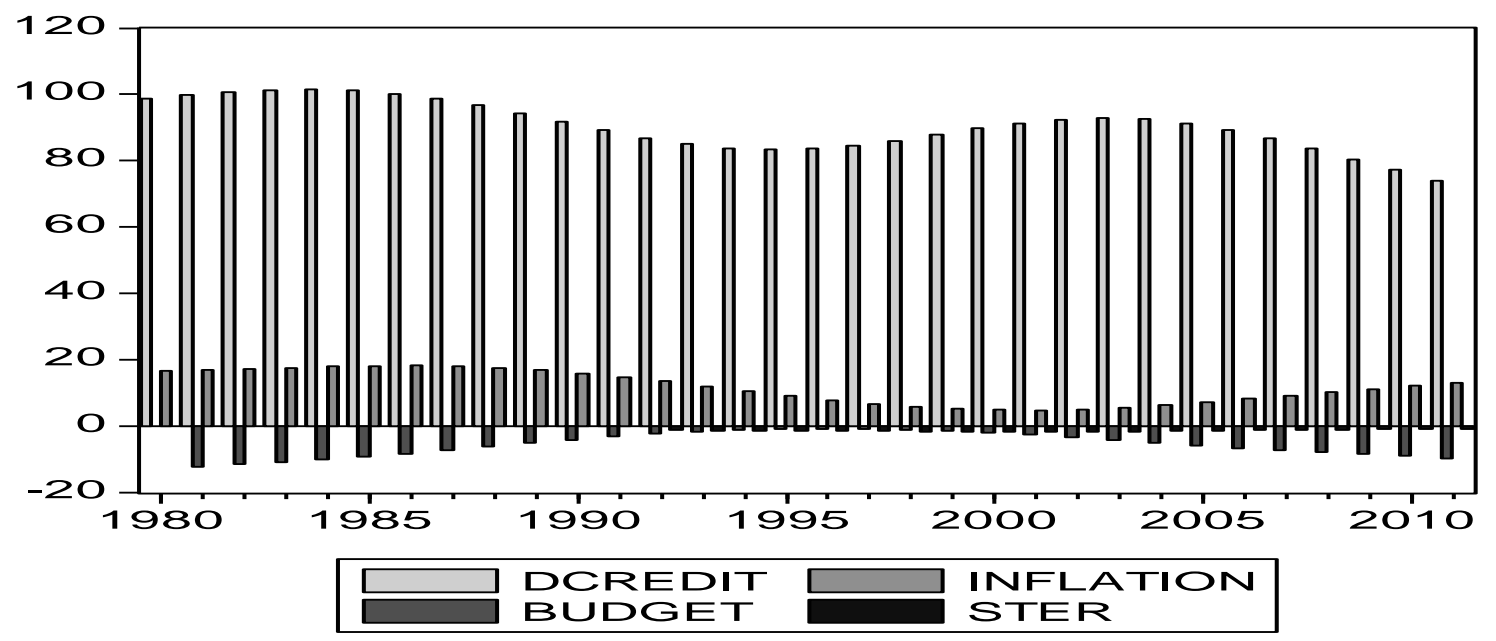

Figure 1. Inflation, Sterilization, Budget balance, and Domestic credit in Egypt: 1980-2011

Apparently the plot shown in figure 1 indicates that all the variables in question are positively correlated meaning that they rise or fall together as time passes. One may see into this a causation link stemming from sterilization and impinging on inflation. Further investigation is needed however to pinpoint the nature of this relationship with the use of a suitable econometric model. The descriptive statistics for the variables are shown in table 2 below (1980-2011).

Table 2 shows the descriptive statistics for the variables (1980-2011)

\begin{tabular}{ccccc}
\hline & STER & INFLATION & BUDGET & DCCREDIT \\
\hline Mean & -1.44 & 11.64 & -5.56 & 90.50 \\
Median & -1.51 & 11.54 & -5.21 & 90.45 \\
Maximum & -0.83 & 18.14 & -0.81 & 101.53 \\
Minimum & -1.83 & 4.76 & -12.29 & 74.00 \\
Std. Dev. & 0.31 & 4.89 & 3.59 & 7.42 \\
Skewness & 0.60 & -0.007 & -0.21 & -0.15 \\
Kurtosis & 2.21 & 1.48 & 1.78 & 2.27 \\
Jarque-Bera & 1.69 & 3.08 & 2.16 & 0.82 \\
Probability & 0.43 & 0.21 & 0.34 & 0.66 \\
Sum & -28.71 & 372.49 & -172.2700 & 2896.00 \\
Sum Sq. Dev. & 1.77 & 741.11 & 387.06 & 1706.14 \\
Observations & 20 & 32 & 31 & 32 \\
\hline
\end{tabular}

\subsection{Unit Root and Counteracted Tests}

Our next step is to test for the stationary of the variables. This is a necessary procedure since it is improper to run time series regressions unless stationary is well in place. A stationary time series may be defined as one, whose mean, variance and autcovariance are invariant over the period under consideration. To test for stationary of the time series we use the

liabilities as time and savings deposits). Examples of other financial corporations are finance and leasing companies, money lenders, insurance corporations, pension funds, and foreign exchange companies. Data source: World Development Indicators (WDI).

5- According to the (HP) scheme, time series may be viewed as composed of transitory and permanent parts. The latter can be set apart by getting the minimum squares sum for the second difference. 
well- publicized Dickey Fuller GLS (ERS) technique to test for the unit roots. Results of this test are reported in table 3 below.

Table3. Summary of Dickey - Fuller GLS (ERS) Unit Root Test Result

\begin{tabular}{lcccccc}
\hline & \multicolumn{3}{c}{ Level } & & \multicolumn{3}{c}{ First-Difference } \\
\hline Variable & constant & Trend & Conclusion & Level & Trend & Conclusion \\
\hline INFLATION & $-4.69^{*}$ & $-3.99^{*}$ & $\mathrm{I}(0)$ & $-1.84^{* * *}$ & -2.82 & $\mathrm{I}(1)$ \\
STER & $-3.23^{*}$ & -2.74 & $\mathrm{I}(0)$ & $-1.79 * * *$ & $-3.33^{* *}$ & $\mathrm{I}(1)$ \\
BUDGET & $-2.70^{*}$ & -2.46 & $\mathrm{I}(0)$ & -0.85 & $-5.56^{*}$ & $\mathrm{I}(1)$ \\
DCCREDIT & 1.71 & -1.275 & & -0.086 & $-3.30^{*}$ & $\mathrm{I}(1)$
\end{tabular}

Notes: 1) For ADF and PP tests, ***, ** and * denote rejection of a unit root hypothesis based on Mackinnon (1991) critical values at $10 \%, 5 \%$ and $1 \%$ respectively.

As can clearly be seen from the results in table 3 , all the model variables are integrated of order one, I (1). That is, they are difference stationary. This allows us to go ahead and test for whether there is a long run co integration relationship between the variables of the model. Once such a relation is established, the next step is to obtain the estimated values of the vector error correction model (VECM) which is a variant of the full information maximum likelihood models. This ensures that the vector estimators are of the highest efficiency possible. The VECM model is advantageous in that it cuts short an otherwise roundabout estimation process into a single step that does not require normalization of the variables concerned. Additionally (VECM) also makes it unnecessary to toil with the usual endogenously or exogeneity assumptions regarding model variables. Thus with VECM, endogenous variables would gravitate towards their long run or equilibrium values but any drifts from these long run values would eventually be corrected. In table 4 below we report the Johansen co-integrated test results for three equations at the 5\% and 190 levels for Trace Max-eigenvalue testes.

Table 4. Summary of Johansen Co-integrated Test

\begin{tabular}{ccccc}
\hline \multicolumn{5}{c}{ Unrestricted Co-integrated Rank Test } \\
\hline $\begin{array}{c}\text { Hypothesized } \\
\text { No. of CE(s) }\end{array}$ & Eigenvalue & $\begin{array}{c}\text { Trace } \\
\text { Statistic }\end{array}$ & $\begin{array}{c}\text { 5per cent } \\
\text { Critical Value }\end{array}$ & $\begin{array}{c}\text { 1per cent } \\
\text { Critical Value }\end{array}$ \\
\hline None $* *$ & 0.99 & 172.53 & 39.89 & 45.58 \\
At most $1 * *$ & 0.96 & 84.74 & 24.31 & 29.75 \\
At most $2 * *$ & 0.73 & 25.69 & 12.53 & 16.31 \\
At most 3** & 0.089 & 1.69 & 3.48 & 6.51 \\
\hline Hypothesized & Eigenvalue & Max-Eigen & 5per cent & 1per cent \\
No. of CE(s) & & Statistic & Critical Value & Critical Value \\
\hline None $* *$ & 0.99 & 87.79 & 23.80 & 28.82 \\
At most $1 * *$ & 0.96 & 59.05 & 17.89 & 22.99 \\
At most 2** & 0.85 & 23.99 & 11.44 & 15.69 \\
At most 3** & 0.73 & 1.69 & 3.84 & 6.51 \\
\hline
\end{tabular}

Note: $*(* *)$ denotesrejectionofthehypothesisatthe5 \%( 1\%) level; Tracetestindicates3co- integrated equation(s) at both5\%and1\%levels; Max-Eigenvalue test indicates 3 co-integrated equation(s) at both 5\% and $1 \%$ levels.

\subsection{Granger Causality Tests}

To test for causality between inflation sterilization, we use the familiar Granger causality test with the number of lag lengths not exceeding 6 periods. Results are reported in table (5). Several conclusions may be drawn from these results, namely that (i) the hypothesis that inflation and domestic bank credit do not Granger cause sterilization is rejected in one lag (ii) the causal link between budget deficit and sterilization is apparently bi-directional and extends from two to five lags. This implies that sterilization is an instigator of fiscal deficit in Egypt, (iii) There is a bi- directional causal relationship between sterilization inflation in two and three lags and inflation Granger causes sterilized intervention in four and five lags. All sterilized interventions by the central bank in Egypt has invariably caused inflation during the period 1980-2011 (iv) There is a bi- directional causal relationship between sterilization and domestic credit extended by the commercial banks in three and four lags while domestic credit provided by banks causes sterilization in five lags. 
Table 5. Results of Granger Causality Tests

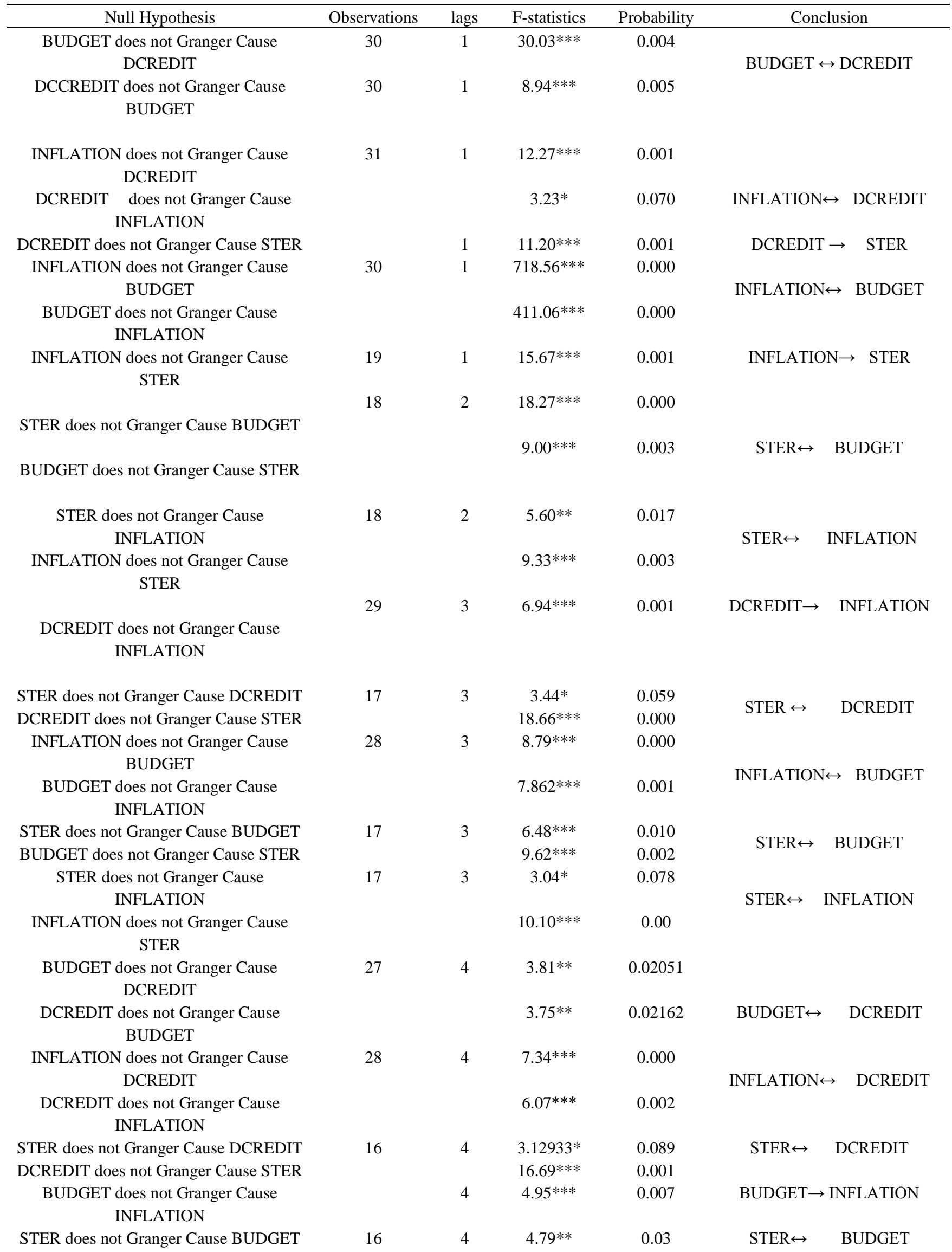




\begin{tabular}{|c|c|c|c|c|c|}
\hline BUDGET does not Granger Cause STER & & & $13.98 * * *$ & 0.001 & \\
\hline $\begin{array}{c}\text { INFLATION does not Granger Cause } \\
\text { STER }\end{array}$ & 16 & 4 & $13.42 * * *$ & 0.002 & INFLATION $\rightarrow$ STER \\
\hline BUDGET does not Granger Cause & & 5 & $2.90 * *$ & 0.049 & \\
\hline DCREDIT & & & & & BUDGET $\leftrightarrow$ \\
\hline $\begin{array}{c}\text { DCREDIT does not Granger Cause } \\
\text { BUDGET }\end{array}$ & & & $3.83 * *$ & 0.019 & \\
\hline INFLATION does not Granger Cause & 27 & 5 & $4.93 * * *$ & 0.006 & \\
\hline DCREDIT & & & & & INFLATION $\leftrightarrow$ DCREDIT \\
\hline $\begin{array}{l}\text { DCREDIT does not Granger Cause } \\
\text { INFLATION }\end{array}$ & & & $4.90 * * *$ & 0.006 & \\
\hline DCREDIT does not Granger Cause STER & 15 & 5 & $6.50 * *$ & 0.046 & DCREDIT $\rightarrow$ STER \\
\hline INFLATION does not Granger Cause & 26 & 5 & $2.93 * *$ & 0.048 & \\
\hline BUDGET & & & & & INFLATION $\leftrightarrow \quad$ BUDGET \\
\hline $\begin{array}{c}\text { BUDGET does not Granger Cause } \\
\text { INFLATION }\end{array}$ & & & $4.56 * * *$ & 0.009 & \\
\hline STER does not Granger Cause BUDGET & 15 & 5 & $10.04 * * *$ & 0.02207 & BUDGET \\
\hline BUDGET does not Granger Cause STER & 15 & 5 & $12.66^{* * *}$ & 0.014 & \\
\hline $\begin{array}{c}\text { INFLATION does not Granger Cause } \\
\text { STER }\end{array}$ & & & 4.15298 & 0.09627 & INFLATION $\rightarrow$ STER \\
\hline
\end{tabular}

Note:*,**,*** indicates statistical significance at the $10 \%, 5 \%$ and $1 \%$ level respectively.

\section{Results}

\subsection{VECM Results}

In equation 5 below we present estimates of the long run and short run relationship between sterilization and inflation.

$\mathrm{D}($ INFLATION $)=-0.008 *($ INFLATION $(-1)+0.93 *$ BUDGET $(-1)+2.20 * \operatorname{STER}(-1)+0.22 *$ DCREDIT $(-1)-19.75)+$
$0.90 * \mathrm{D}($ INFLATION $(-1))-0.22 * \mathrm{D}($ BUDGET $(-1))-0.30 * \mathrm{D}($ STER $(-1))+0.037 * \mathrm{D}($ DCREDIT $(-1))+0.06$

Table (6) also portrays these same estimates in a tabular form. Deviations by any of the variables from their long run equilibrium values would presumably be corrected through the dynamic long run movement of VECM. It is probably clear from these estimates that there is a long run positive relationship between inflation, sterilized intervention, budget deficit and domestic credit created by commercial banks. In particular, if the budget deficit rises by 10 percent, this would trigger an increase in the inflation rate by 9.3 percent. Likewise, if the sterilized intervention value goes up by $10 \%$, the inflation rate will respond with a 22 percent hike. Turning to the domestic credit extended by commercial banks, it can be seen that a 10 percent increase therein would result in a 2.2 percent increase in the rate of inflation. Not unexpectedly all the explanatory variables were found to be insignificant in the short run except for the impact of the inflation rate on the same which was found to be positive and significant. This may be taken as an indication that sterilized intervention by the CBE does not curb inflation in the short run but leads to higher inflation in the long run through its influence on the budget deficit. As the sterilized intervention value goes up by 10 percent, the budget deficit rises in turn by 4.4 percent.

Table 6. Summary of over parameterized ECM Result

\begin{tabular}{cccc}
\hline variable & coefficient & Std. Error & t-Statistic \\
\hline $\begin{array}{c}\text { BUDGET(-1) } \\
(-1)\end{array}$ & 0.93 & 0.035 & 26.72 \\
DCREDIT(-1) & 0.22 & 0.008 & 26.93 \\
STER(-1) & 2.21 & 0.15 & 14.27 \\
C & -19.75 & & \\
& -0.008 & 0.014 & -0.60561 \\
Error Correction & & & \\
& & & \\
D(INFLATION(-1)) & 0.906 & 0.0 & 11.96 \\
& & 76 & -0.99 \\
D(BUDGET(-1)) & -0.22 & 0.2 & 2 \\
\hline
\end{tabular}




\begin{tabular}{cccc}
\hline D(DCREDIT(-1)) & 0.037 & 0.0 & 1.58 \\
D(STER(-1)) & -0.31 & 0.28 & -1.34 \\
R-squared & 0.99 & $\begin{array}{c}\text { Akaike } \\
\text { Information }\end{array}$ & -20.26 \\
Adj. R-quared & 0.99 & Criteria \\
Log likelihood & 224.95 & $\begin{array}{c}\text { SchwarzCrite } \\
\text { ria }\end{array}$ & -18.88 \\
& \multicolumn{3}{c}{ F-statistic } \\
\end{tabular}

\subsection{Variance Decomposition Result}

We now examine the variance decomposition which allows us to see the extent to which the variables in the auto regression are affected by each single variable therein. The variance decomposition in fact determines the size of the variation in forecast error which can be attributed to exogenous shocks experienced by the other variables. That is, they show us what portion of the change in all the variables taken together may be attributed to each single variable by itself.

Table 7. Variance Decomposition of Inflation

\begin{tabular}{cccccc}
\hline Period & S.E. & INFLATION & STER & BUDGET & DCREDIT \\
\hline 1 & 0.02 & 100 & 0 & 0 & 0 \\
2 & 0.04 & 97.65 & 1.57 & 0.78 & 0.003 \\
3 & 0.06 & 93.58 & 5.5 & 0.91 & 0.013 \\
4 & 0.09 & 88.52 & 10.94 & 0.51 & 0.03 \\
5 & 0.11 & 82.44 & 17.09 & 0.43 & 0.04 \\
6 & 0.14 & 75.49 & 23.37 & 1.096 & 0.048 \\
7 & 0.17 & 68.05 & 29.45 & 2.45 & 0.049 \\
8 & 0.2 & 60.61 & 35.18 & 4.16 & 0.046 \\
9 & 0.23 & 53.6 & 40.5 & 5.85 & 0.038 \\
10 & 0.26 & 47.29 & 45.42 & 7.256 & 0.031 \\
\hline
\end{tabular}

Table 8. Variance Decomposition of STER

\begin{tabular}{cccccc}
\hline Period & S.E. & INFLATION & STER & BUDGET & DCREDIT \\
\hline 1 & 0.02 & 0.78 & 99.22 & 0.00 & 0.00 \\
2 & 0.03 & 1.89 & 89.70 & 8.40 & 0.01 \\
3 & 0.05 & 2.30 & 76.93 & 20.77 & 0.01 \\
4 & 0.06 & 2.19 & 66.77 & 31.03 & 0.01 \\
5 & 0.08 & 1.90 & 60.04 & 38.05 & 0.01 \\
6 & 0.09 & 1.62 & 56.01 & 42.37 & 0.01 \\
7 & 0.09 & 1.40 & 53.78 & 44.81 & 0.01 \\
8 & 0.10 & 1.26 & 52.68 & 46.05 & 0.01 \\
9 & 0.10 & 1.18 & 52.21 & 46.61 & 0.01 \\
10 & 0.11 & 1.16 & 52.04 & 46.79 & 0.01 \\
\hline
\end{tabular}

Table 9. Variance Decomposition of BUDGET

\begin{tabular}{cccccc}
\hline Period & S.E. & INFLATION & STER & BUDGET & DCREDIT \\
\hline 1 & 0.02 & 1.06 & 14.72 & 84.22 & 0.00 \\
2 & 0.03 & 1.12 & 4.24 & 94.64 & 0.00 \\
3 & 0.04 & 1.12 & 4.41 & 94.47 & 0.00 \\
4 & 0.06 & 1.27 & 11.08 & 87.65 & 0.01 \\
5 & 0.07 & 1.77 & 21.44 & 76.78 & 0.01 \\
6 & 0.07 & 2.89 & 32.66 & 64.44 & 0.01 \\
7 & 0.08 & 4.87 & 42.34 & 52.79 & 0.01 \\
8 & 0.10 & 7.66 & 49.33 & 43.00 & 0.01 \\
9 & 0.11 & 10.92 & 53.65 & 35.40 & 0.02 \\
10 & 0.12 & 14.18 & 55.89 & 29.89 & 0.04 \\
\hline
\end{tabular}


Table 10. Variance Decomposition of DCREDIT

\begin{tabular}{cccccc}
\hline Period & S.E & INFLATION & STER & BUDGET & DCREDIT \\
\hline 1 & 0.02 & 84.50 & 0.55 & 2.16 & 12.79 \\
2 & 0.06 & 58.45 & 5.51 & 31.43 & 4.61 \\
3 & 0.12 & 50.96 & 4.96 & 41.94 & 2.14 \\
4 & 0.21 & 51.91 & 3.58 & 43.32 & 1.18 \\
5 & 0.31 & 56.36 & 2.37 & 40.55 & 0.72 \\
\hline 6 & 0.41 & 62.23 & 1.50 & 35.81 & 0.46 \\
7 & 0.50 & 68.30 & 0.97 & 30.41 & 0.31 \\
8 & 0.60 & 73.79 & 0.80 & 25.19 & 0.22 \\
9 & 0.68 & 78.20 & 0.98 & 20.65 & 0.17 \\
10 & 0.76 & 81.32 & 1.52 & 17.02 & 0.14 \\
\hline
\end{tabular}
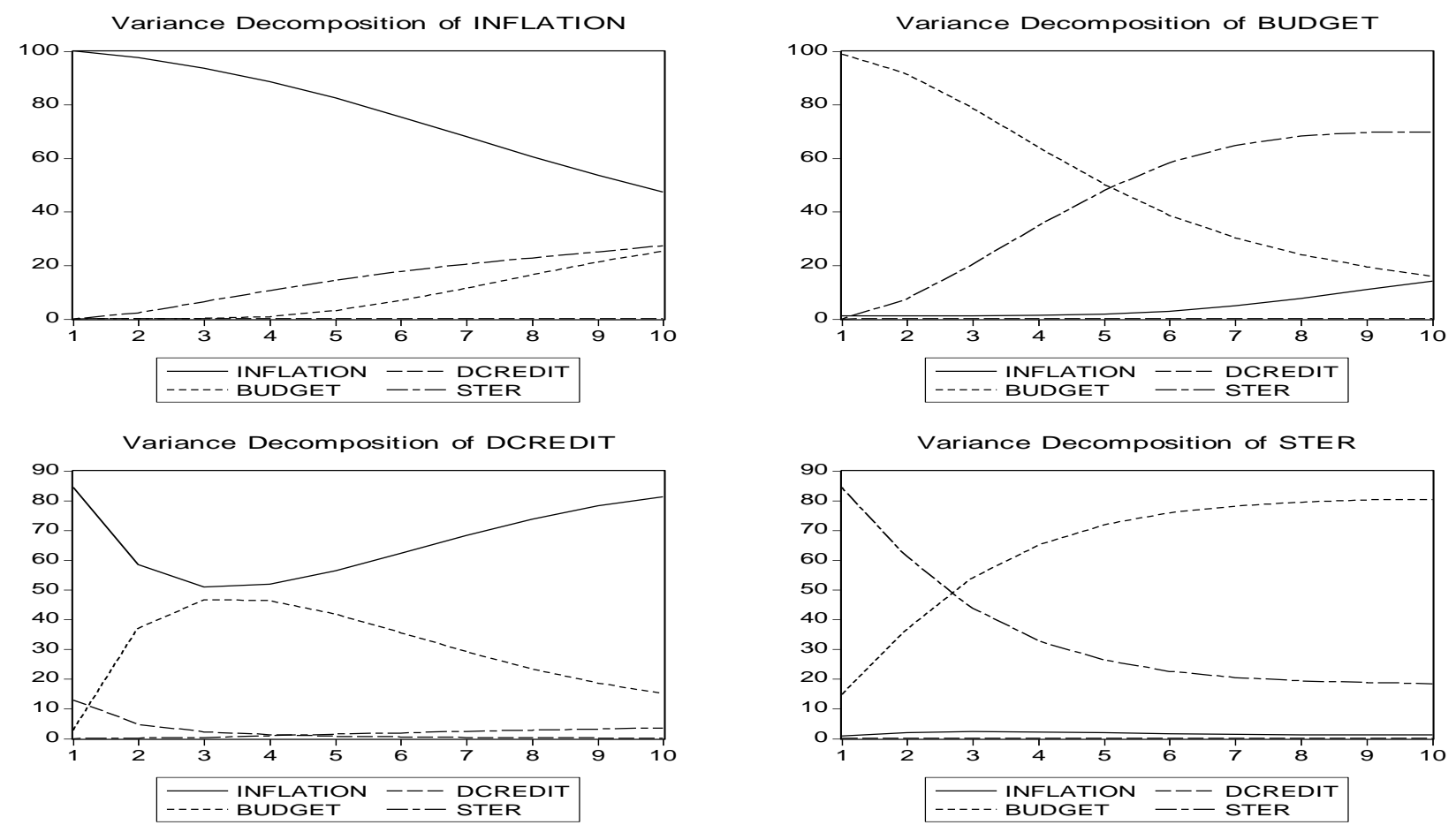

Figure 2. Variance Decomposition of Sterilization and Inflation

Judging from tables 7, 8, 9, 10 and figure 2, it can be seen that the relative importance (contrast ratio prediction error interpreter) of a sterilization shock in explaining variations in inflation is positive, durable and rising. It amounted to 1.56 percent in the second period of the shock, 5.49 percent in the third period, 10.94 percent in the fourth year and then to as high as 45.42 percent after ten years following the shock. This confirms that there is a positive, durable and growing association between sterilized intervention and inflation in Egypt for the time- period under consideration. Further, considering figure 1 and Appendix, it can easily be deduced that there is a direct and continuing relationship between sterilized intervention shocks and variations in the budget deficit. The importance of such sterilization shocks is as high as 14.4 7percent in the first year but then declines in the second and third years before taking an upward turn in the fourth and subsequent years until it reaches 55.88 percent in the tenth year of the shock. Apparently these result point to a positive and durable relation that links sterilized intervention and budget deficit in Egypt for the time period which this study covers.

\section{Conclusion}

In this paper we have attempted to identify the fact that the relationship between sterilization and inflation in Egypt in the period 1980-2011.The causal relationship between sterilization and inflation refers to there is a bi-directional causality in two and three lags and inflation cause sterilization in four and five lags, that any intervention by the central bank sterilization in Egypt is causing inflation in the period 1980-2011. The VECM results clearly indicate the existence of a 
long run positive relationship between sterilization and inflation, where sterilization value increased by $10 \%$ the change in inflation will be $22 \%$ but in the short term, all the independent variables were not significant except for the impact of inflation on the same, it is positive and significant. This means that the results of the intervention of the Central Bank of Egypt through the sterilization policy does not limit the inflation in the short term but lead to increased rates of inflation in the long term through the influence in the fiscal deficit, as the sterilization value increased by $10 \%$ the change in budget deficit will be $4.4 \%$. The variance decomposition rustles indicates that the relative importance (contrast ratio prediction error interpreter) for a shock occur in sterilization in the interpretation of the change in inflation is positive, continuing and growing, this importance was $1.56 \%$ in the second year of shock and then $5.49 \%$ in the third year of the shock and then $10.94 \%$ in the fourth year and so that up to $45.42 \%$ in the tenth year of the shock. This indicates that there is a positive, growing and continuing relationship between sterilization and inflation in Egypt in the period of study.

\section{References}

Calvo, G. (1991). The Perils of Sterilization. IMF Staff Paper, 38, 4. http://dx.doi.org/10.2307/3867130

Central Bank of Egypt. (2009). Economic Review, 50, 3

Cun, W., \& Jie, L. (2013). Foreign Exchange Market Intervention, Inflation and Export Competitiveness. http://econweb.rutgers.edu/rchang/paper_mar_cun.pdf

Dalton, J., \& Dziobek, C. (2005) .Central Bank Losses and Experiences in Selected Countries. IMF Working Paper, WP/05/72. https://www.imf.org/external/pubs/ft/wp/2005/wp0572.pdf

Disyatat, P., \& Galati, G. (2005). The Effectiveness of Foreign Exchange Intervention in Emerging Market Countries: Evidence from the Czech Koruna. BIS Working Paper, 172.

Edison, H. J. (1993).The Effectiveness of Central-Bank Intervention: A Survey of the Literature after 1982. Special Papers in International Economics, International Finance Section, Princeton University, 18. https://www.princeton.edu/ ies/IES_Special_Papers/SP18.pdf.

Frankel, J. (1997). Sterilization of Money Inflows: Difficult (Calvo) or Easy (Reisen).Estudios de Economia, $24,2$. http://www.imf.org/external/pubs/cat/longres.aspx?sk=1850

Lavigne R. (2008). Sterilized Intervention in Emerging-Market Economies: Trends, Costs, and Risks. Bank of Canada, Discussion Paper. 1-25. http://www.bankofcanada.ca/wp-content/uploads/2010/01/dp08-4.pdf

Moreno, R. (1996). Intervention, Sterilization, and Monetary Control in Korea and Taiwan. FRBSF Economic Review, 3 , 23-33. http://www.frbsf.org/economic-research/publications/96-3/moreno.pdf

Mundell, R. (1968). International Economics. New York: Macmillan.

Obstfeld, M. Exchange Rate, Inflation, and the Sterilization Problem: Germany, NBER Working Paper, 963. http://www.researchgate.net/publication/4862156_Exchange_rates_inflation_and_the_sterilization_problem_Germ any_1975-1981

Reinhart, C., \& Khan, M. (1995). Macroeconomic Management in APEC Economies: The Response to Capital Inflows. MPRA Paper148, University Library of Munich, Germany.

Yung Lee, (1997). Sterilizing Capital Inflows. IMF. https://www.imf.org/EXTERNAL/PUBS/FT/ISSUES7/INDEX.HTM

\section{(cc) $\mathrm{BY}$}

This work is licensed under a Creative Commons Attribution 3.0 License. 